\title{
Storynomics Tourism as an Effective Marketing Strategy on Tourism Destination (Case Study on Tangkuban Parahu, West Java-Indonesia)
}

\author{
Titing Kartika ${ }^{1}$, Nova Riana ${ }^{2}$
}

${ }^{1}$ Tourism Management Department, Sekolah Tinggi Ilmu Ekonomi Pariwisata Yapari, Indonesia ${ }^{2}$ Hotel Department, Sekolah Tinggi Ilmu Ekonomi Pariwisata Yapari, Indonesia

\begin{abstract}
The purpose of this study is to find out how the storynomics tourism approach can be used as an effective tourism marketing destination. In this case, Tangkuban Parahu in West Java, Indonesia. Tangkuban Parahu has historical and folklore values that are trusted by the wider community so that this will build the branding power of the destination. The challenge is how this message can be conveyed to tourists not only convey the value of myth but also packaged in other forms so as to provide educational value to each visitor. The research method used is qualitative descriptive. Data collection is done through observation, documentation, and interviews. The results show that the storynomics approach can be used as an effective strategy in marketing the Tangkuban Parahu destination, which can indirectly increase interest in visiting the place.
\end{abstract}

Keywords: Storynomics tourism, marketing communication, destination, Tangkuban Parahu

This is an open access article under the CC-BY-NC license.

\section{INTRODUCTION}

The tourism sector is a priority for Indonesia's national development in addition to the food, energy, maritime, and zones industrial \& Special Economic Zones. Indonesia has a unique and diverse culture and hundreds of tribes. According to data from the Central Statistics Agency (2010), 1340 ethnic groups live in various parts of the archipelago. Each tribe has a religious background, cultural customs, and social conditions. Likewise with the potential of natural tourism which is spread in every province in Indonesia. What is of interest in this research is the existence of Tangkuban Parahu Mountain as a very strong natural tourism destination with the folklore of Sangkuriang. This folklore is part of the cultural heritage based on local cultural values.

Tangkuban Parahu Mountain is one of the attractions located in northern Bandung / Lembang, West Java Province. Geologically, Tangkuban Parahu volcano is formed from the youngest eruption activity among the Sunda Purba volcanic mountain ranges with a type of layer eruption which produces several eruption centers called eruption centers which happened around 3000 years ago.

In connection with the existence of folklore, as well as other aspects such as geography and volcanology, this research is intended to find out how the story attached to Mount Tangkuban Parahu becomes a strategy in marketing destinations with a storynomics approach. 
Tourism and Sustainable Development Review Journal (TSDR), Vol. 1 (1), 33-40

Storynomics Tourism as an Effective Marketing Strategy on Tourism Destination (Case Study on

Tangkuban Parahu, West Java-Indonesia)

Titing Kartika, Nova Riana

\section{LITERATURE REVIEW}

Storynomics and Interpreting Concept

Storynomics Tourism is an approach that prioritizes narration, creative content, and living culture and uses the power of culture as destination DNA. This formula was socialized by Irfan Wahid, who was assigned by President Joko Widodo to lead the Quick Win 5 Tourism Super Priority Destination team (kompas.Com, 1 August 2019). The storynomics concept was adapted from the marketing field by McKee (McKee and Gerace, 2018). By preparing a good story, the marketing process becomes different. A story that has economic value can attract people in making a purchasing decision. In terms of tourism destinations, this economic value story is folklore, which can attract tourists in deciding to visit.

Mckee also explained that the concept of storynomics is to compose a story; it requires regular and planned steps so that the story can amaze its listeners or readers. Currently, marketing through advertising has begun to fade. Thus storytelling will be an opportunity for marketing as a substitute for saturation from advertising. Marketing experts, including advertising companies, were forced to admit that in this digital age, marketing strategies have indeed gone from "Advertising is King" to "Content is King". Furthermore, McKee also distinguishes between Fictional Story and Purposeful Story, which is a real difference between story for storytelling (fictional), which is different from the process of a story that contains a purpose (purposeful), which requires Action.

However, the concept of storytelling can be seen in a broader context. Destination information provides not only complete information on available infrastructure and amenities but also interesting stories were written by geologists, the environment, maritime, and cultural experts, which are translated into various target market languages.

In several studies show that several factors can affect the interest in visiting a destination, one of which is a myth about the destination. Amanat (2019) explained that folklore (myth) is part of the strategy for developing tourist destinations.

The Storynomics concept is closely related to the delivery of messages to tourists. The party that has the most role in delivering this message is a tour guide. In a broad context, the function of a tour guide is not only to guide tourists during the tour but also to convey a variety of information related to the destination from various points of view (Kesrul, 2004). Another ability that must be possessed is interpreting ability.

Prideau (2006) describes interpretation as a special type of communication that is highly relevant to tourism. According to him, the importance is seen in activities such as tours, presentations, and educational programs carried out in museums, art galleries, information centers, wildlife parks, zoos, national parks, and other protected environments. People who carry out interpretation activities are called interpreters. Another definition of interpretation is educational activities aimed at expressing various meanings and relationships through the use of original objects, in a direct way, with illustrative media, more than just conveying factual information (Carter, 1997). The role of an interpreter is very necessary for tourism activities. Resource interpretation connects visitors to the meaning and spirit of places (Benton, 2007). Another opinion states: the role of interpretation in tourist experience is widely acknowledged (Sam, 2007). With the value of experience gained from tourists will have an impact on return visits to a destination (Yuniawati, 2016) 
The principles that the guide must pay attention to when interpreting are:

1. Possession of adequate factual information, research results, or from written sources, as well as from sources that are not recorded, such as trust that grows in the community, people's perceptions about something, as well as technical information about objects.

2. The ability to reveal the truth through the information held.

3. Utilization of information to show the relationship between the object being interpreted with the visitors. This association is different for different groups of visitors, for example, between children and adult humans, or between Japanese tourists and European or domestic tourists. It is linking something that is interpreted with the daily group of visitors.

4. The ability to persuade visitors to become interested, through skills and communication media to attract attention. The guide must have an understanding of the visitors' interests.

5. Delivering interpretation in its entirety does not give the impression that we only know but understand correctly about what is being interpreted.

\section{Marketing Communication}

Related to the activities of interpreting information to consumers, in this case, is tourists, a marketing communication approach is needed. Integrated marketing communication (IMC) is a concept in which a company integrates and coordinates various communication channels to send clear, consistent, and convincing messages regarding the company and its products (Kotler and Armstrong, 2005).

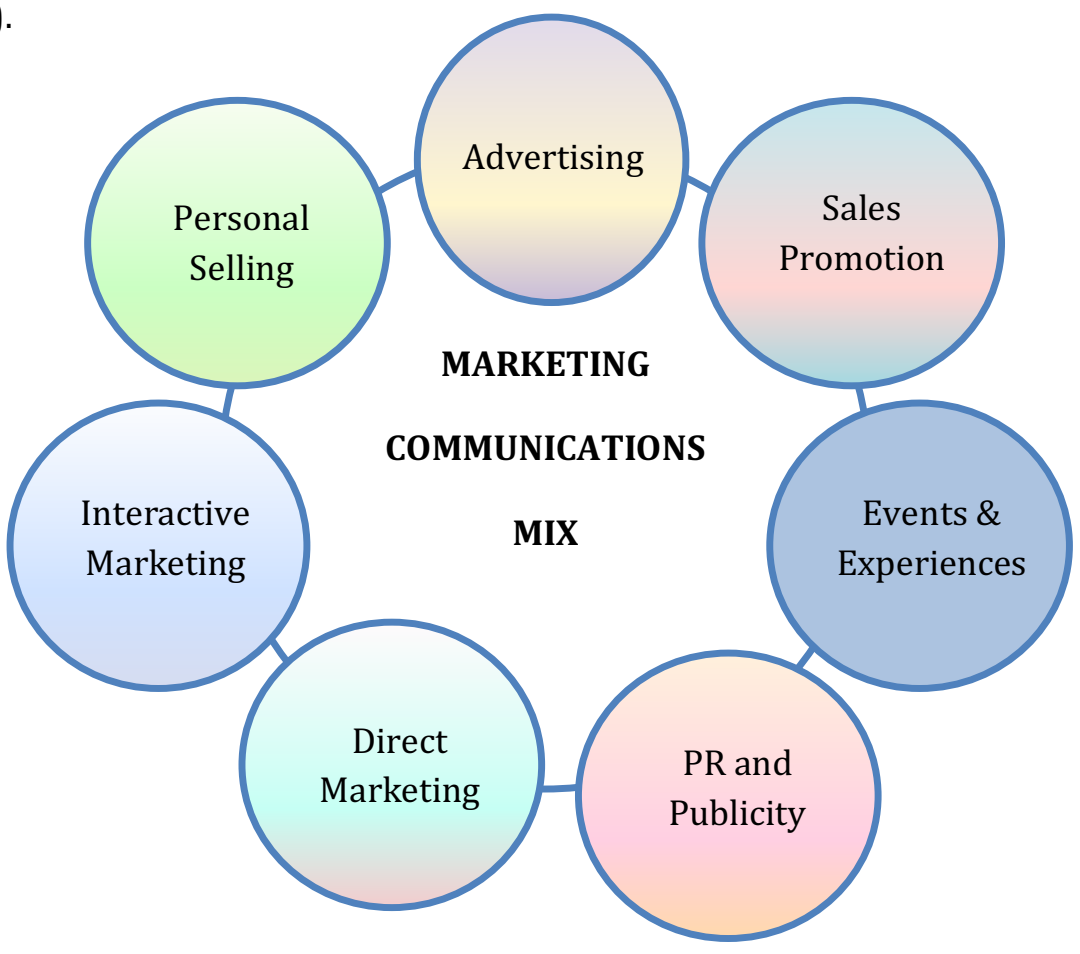




\section{Figure 1: Components in IMC}

IMC is a simple concept that unites all forms of communication into a single solution. In essence, IMC integrates all promotional tools so that these tools can work together in harmony (Smith, 1996: 22).

From the various components of the IMC, it can be understood that all components are directly related to the customer. This confirms that Marketing Communication is a specification of the relationship between communication and marketing, where marketing communication is a merger of two studies, namely communication and marketing science. In general, marketing communication is a marketing activity by utilizing communication techniques aimed at providing information to many people in the hope of achieving the company's goals, namely increasing revenue. In its implementation of the tourism business, marketing communication strategies can be carried out in various channels, including by utilizing the Storynomics formula. In figure 1 above, Storynomics can be attached to all components in the IMC.

Marketing communication has several characteristics (Lovelock and Wright, 2007):

1. Inform and educate prospective consumers about the goods and services to be sold.

2. Persuade the target consumer by explaining that the product being sold is the best compared to its competitors. The product must create the impression that the product can meet the needs of consumers.

3. Remind customers to re-buy the product.

4. Maintaining good relations with regular customers and providing updates and further explanation about the product. This explanation must cover how the customer can get the best results or experience in using the product.

Another approach is referring to Koentjaraningrat (2008), communication ethnography is "the study of language in communication and social behavior in society (which is then called speech society), covering the ways and how language is used in different societies and cultures." Based on this understanding, two things become an outline in the study of communication ethnography, namely language and culture.

Meanwhile, in marketing, the concept of loyalty emphasizes the willingness of consumers to continue to be loyal to a company in the long run, by buying and using goods and services repeatedly and even better exclusively, and voluntarily recommending the company's products to those around ( Lovelock and Wright, 2007).

\section{RESEARCH METHOD}

The method used in this research is a descriptive qualitative method. Meanwhile, data collection is done through observation, interviews, and literature studies. The data obtained were then analyzed qualitatively, including data collection, data reduction, data display, and drawing conclusions or verification (Milles and Huberman, 1992). Interviews were conducted with the manager of Tangkuban Parahu, tourists, tour guides, related associations such as the Indonesian Guides Association, Association of The Indonesian Tours And Travel Agencies (ASITA) of West Java and the Tangkuban Parahu volcanology researcher

\section{FINDINGS AND DISCUSSION}


As the object of research is Mount Tangkuban Parahu, located in north Bandung-Lembang. This destination is visited by many domestic and foreign tourists. Based on statistical data from the Statistics Center for Conservation of Natural Resources in West Java (2017), the number of visits from 2013-2017 looks volatile. Based on interviews, this is caused by several factors, including weather factors and natural disaster issues such as earthquakes and volcanic eruptions. The number of visits can be seen in Table 1 below:

\begin{tabular}{|c|c|c|c|c|c|c|c|c|c|c|c|}
\hline No. & Month & \multicolumn{2}{|c|}{$\mathbf{2 0 1 3}$} & \multicolumn{2}{c|}{$\mathbf{2 0 1 4}$} & \multicolumn{2}{c|}{$\mathbf{2 0 1 5}$} & \multicolumn{2}{c|}{$\mathbf{2 0 1 6}$} & \multicolumn{2}{c|}{$\mathbf{2 0 1 7}$} \\
\hline & & $\mathrm{D}$ & $\mathrm{I}$ & $\mathrm{D}$ & $\mathrm{I}$ & $\mathrm{D}$ & $\mathrm{I}$ & $\mathrm{D}$ & $\mathrm{I}$ & $\mathrm{D}$ & $\mathrm{I}$ \\
\hline 1 & Jan & 115.213 & 14.29 & 111.919 & 4.998 & 46.053 & 4.998 & 148.68 & 5.609 & 177.388 & 5.86 \\
\hline 2 & Feb & 54.56 & 13.88 & 59.656 & 7.867 & 64.658 & 7.867 & 103.365 & 6.756 & 82.259 & 4.91 \\
\hline 3 & Mar & 24.954 & 8.714 & 83.569 & 8.659 & 81.045 & 8.659 & 110.929 & 7.438 & 101.591 & 6.25 \\
\hline 4 & Apr & 43.492 & 13.82 & 70.269 & 7.223 & 82.216 & 7.223 & 97.267 & 6.464 & 123.076 & 5 \\
\hline 5 & May & 87.119 & 20.62 & 135.526 & 8.897 & 152.001 & 8.897 & 176.571 & 7.582 & 116.926 & 4.85 \\
\hline 6 & Jun & 124.406 & 23.29 & 118.819 & 9.061 & 99.664 & 9.061 & 59.372 & 7.582 & 111.404 & 3.01 \\
\hline 7 & Jul & 58.444 & 11.53 & 106.242 & 6.246 & 178.466 & 6.246 & 208.476 & 7.137 & 146.022 & 7.93 \\
\hline 8 & Aug & 169.803 & 13.68 & 143.902 & 12.32 & 118.333 & 12.32 & 104.561 & 11.66 & 87.884 & 8.73 \\
\hline 9 & Sept & 83.041 & 18.45 & 79.142 & 9.604 & 91.799 & 9.604 & 98.638 & 8.399 & 90.158 & 5.72 \\
\hline 10 & Oct & 8.25 & 2.832 & 93.875 & 511 & 102 & 511 & 99.635 & 5.974 & 89.576 & 5.03 \\
\hline 11 & Nov & 64.92 & 20.97 & 94.35 & 7.809 & 95.473 & 7.809 & 84.691 & 6.41 & 81.597 & 4.1 \\
\hline 12 & Dec & 139.525 & 28.64 & 167.972 & 9.119 & 201.724 & 9.119 & 219.898 & 8.759 & 207.862 & 6.21 \\
\hline \multirow{2}{*}{ Total } & & 973.727 & 190.7 & 1.265 .241 & 92.32 & 1.211 .534 & 92.32 & 1.512 .083 & 86.7 & 1.415 .746 & 67.6 \\
\cline { 2 - 10 } & & $\mathbf{1 . 1 6 4 . 4 7 3}$ & $\mathbf{1 . 4 5 2 . 9 1 9}$ & $\mathbf{1 . 3 0 3 . 8 4 9}$ & $\mathbf{1 . 5 9 8 . 7 7 8}$ & $\mathbf{1 . 4 8 3 . 3 4 6}$ \\
\hline
\end{tabular}

Table 1. Tourist Arrival to Tangkuban Perahu

Source: Statistics of the Center for Conservation of Natural Resources in West Java (2017) $\mathrm{D}=$ Domestic Tourist $/ \mathrm{I}=$ International Tourist

Geologically, Tangkuban Parahu volcano was formed from the youngest eruption activity among the Sunda Purba volcanic eruption with a layer that produced several eruption centers called eruption centers, and that happened around 3000 years ago. Based on historical records, Tangkuban Parahu, which is located at an altitude of 2,084 meters above sea level and is located approximately $30 \mathrm{~km}$ north of Bandung in 1.5 centuries, has erupted several times. Aside from the captivating scenery, visitors can see the active volcano crater, Ratu's crater, which is located at an altitude of $1,830 \mathrm{~m}$ above sea level.

In its development, it formed the body of a mountain with an extending peak of a volcano. Elongated body shape caused by the displacement of the eruption point that extends from east to west with a distance of 1,100 meters. This is caused by the existence of a place to move the activity 
Tourism and Sustainable Development Review Journal (TSDR), Vol. 1 (1), 33-40

Storynomics Tourism as an Effective Marketing Strategy on Tourism Destination (Case Study on

Tangkuban Parahu, West Java-Indonesia)

Titing Kartika, Nova Riana

in the top of the mountain, which stretches from east to west, so when viewed from the south (the city of Bandung), it looks like a trapezoid and looks like an upside-down boat.

Storynomics as a Tourism Marketing Strategy

The Folklore and Storynomics Concept

In Sundanese society, the formation of Tangkuban Parahu mountain is inseparable from the folklore of Sangkuriang. The story begins with a man named Sangkuriang, who, since childhood, was separated from his mother, Dayang Sumbi. Both were reunited when Sangkuriang turned into an adult. He does not know his mother because Dayang Sumbi still looks beautiful and youthful. Not recognizing, Sangkuriang fell in love with Dayang Sumbi and intended to propose to her. However, accidentally, Dayang Sumbi saw the birthmark on the Head of Sangkuriang, and he also realized that Sangkuriang was his long-lost child.

When Dayang Sumbi talked about it, Sangkuriang remained stubborn and did not believe him. Then Dayang Sumbi gave conditions to Sangkuriang if he still wanted to marry her. The condition is, Sangkuriang must make a boat in one night. Sangkuriang agreed.

Sangkuriang passionately tried to finish the boat that must be made in one night. Seeing the boat was almost finished, Dayang Sumbi did not remain silent, and she made plans to frustrate it. Then, Dayang Sumbi woke the chicken with a cloth that had been given light so that the chicken thought it was morning. His efforts were successful. Sangkuriang looks annoyed because his efforts failed; he even with anger and anger kicked the unfinished boat upside down and became a mountain. This folklore is believed to be the beginning of the formation of Mount Tangkuban Parahu.

In the Tangkuban Parahu case study, Storynomics is packaged as a manifestation of the packaging theory from Lovelock and Wright in the form of the folklore of the formation of Tangkuban Parahu mountain. Product packaging in the form of folklore can be important in marketing communication strategies. An interesting story can influence tourists' decisions when visiting Tangkuban Parahu.

\section{Vulcanology Interpretation}

Developing the concept of Storynomics in the Tangkuban Parahu destination, the narrative context can be developed in terms of volcanology. Through volcanological interpretation, tourists will gain knowledge about the history of volcanic eruptions that occurred in Tangkuban Parahu. This nature and history education will strengthen the existence of Tangkuban Parahu to be better known by the global community.

Mount Tangkuban Parahu is a volcano and is monitored by the Indonesian Volcanology Directorate Agency. Some mountain craters also still provide active mountain signals. This active sign can be seen with the emergence of sulfur gas and fire water sources at the foot of the mountain, such as in the Ciater region, Subang. Throughout history, activities that occurred on Mountain Tangkuban Parahuhave formed 13 craters. Three of them are popular tourist destinations such as Ratu Crater, Upas Crater, and Domas Crater. Meanwhile, the other 13 craters are Upas Crater (youngest), Upas Crater (young), and Upas Crater (old). Kawah Ratu also has Kawah Ratu (1920), 
Kawah Ratu (young), and Kawah Ratu (old). Then there are the New Crater, Pangguyangan Budak Crater, Badak Crater, Ecoma Crater, KAwah Jurig, Silumna Crater, and Domas Crater.

The eruption activity occurred in 1910, 1929, 1935, 1946, 1947, 1950, 1952, 1957, 1961, 1965, 1967, 1969, 1971, 1983, 1992, 1994, and 2004. The rest period between the eruption of Mount Tangkuban Parahu lasted between 30 -70 years old (Bachtiar, 2004).

If you look at the history of the eruption of Tangkuban Parahu, this data will be interesting if it is developed into a narrative in a volcanological perspective. Tourists will be rich in understanding the existence of the mountain both from the knowledge of the natural environment and history.

\section{CONCLUSION}

Tangkuban Parahu is one of the attractions located in northern Bandung / Lembang. Geologically, the Tangkuban Parahu volcano is formed from eruption activity. The folklore of Sangkuriang, which is strong among the people, has become one of the attractions of tourists, especially from domestic. The strength of folklore and other supporting aspects and its relation to storynomics can be used as an effective marketing strategy for the Tangkuban Parahu destination. This concept not only conveys folklore but how visitors can experience when visiting with detailed information about Mount Tangkuban Parahu from various perspectives, for example, from the perspective of geography, volcanology, and local culture. It can be enriching, and tourists will get to experience, travelers experience is what will build a strong memory to a destination that directly or indirectly will have an impact on a return visit (revisit) or also in providing information to other parties.

\section{ACKNOWLEDGMENT}

We would like to thank those who helped in the completion of this research. Manager, author of the book "Bandung Purba: T. Bactiar who has described Tangkuban Parahu Mountain in terms of geology and volcanology, and the local community.

\section{REFERENCES}

McKee, R. and Gerace, T. (2018) Storynomics: Story-driven Marketing in the Post-advertising World. Hachette UK.

Bachtiar ,T. and Sayfriani, D. (2004). Lindungi Pusaka Bumi Bandun. Bandung Purba. Masyarakat Geografi Indonesia.

Badan Pusat Statistik (2010), Jumlah Suku di Indonesia

Benton, G.(2007). From Principle to Practice : Four Conceptions of Interpretation, Interpretation RESEARCH. The National Association for Interpretation. Volume 12 number 2

Carter, J. (1997). A Sense of Place : An interpretive planning handbook. The Tourism and Environment Initiative, Bridge House, Bridge Street, Inverness IV1 1QR

Dirgantara (2016). Peran Interpreter dalam Kegiatan Geowisata: Studi Kasus Gunung Tangkuban Perahu, An aCademic Article.

Kesrul, M. (2004). Panduan Praktis Pramuwisata Profesional, Graha Ilmu Yogyakarta. Koentjaraningrat (2008). Metode Penelitian Masyarakat. PT. Gramedia. Jakarta 
Kompas.com. Destinasi Wisata Superprioritas, downloaded December 2019

Kotler, P., Armstrong, G. (2005). Principles of Marketing, 9th edn. Prentice Hall, Englewood Cliffs Lovelock, Christopher H., Wright, Lauren K.(2007). Manajemen Pemasaran Jasa. 2nd edn. Indeks. Jakarta.

McKee, R. (2018). Storynomics, Story-Driven Marketing in the Post-Advertising World", Twelve, New York-Boston

Miles M.B. dan Huberman, A.B. (1992). Analisis Data Kualitatif. Jakarta: UI Press.

Paul.S. (1996). Benefits and Barriers to Integrated Marketing Communication, Admap

Prideau, B. Moscardo, G \& Laws E. (2004). Managing Tourism and Hospitality Services, Theory and International Application, CABI, London UK.

Sam H. and Weiler, B. (2007). Isolating the Role of On-site Interpretation in a Satisfying Experience. Journal of volume 12 number 2, interpretation RESEARCH. The National Association for Interpretation.

Yuniawati, Y. Finardi, A. (2016). Pengaruh Customer Experience terhadap Revisit Intention di Taman Wisata Alam Gunung Tangkuban Perahu. Tourism and Hospitality Essentials (THE) Journal Vol VI No.1 Page 983-994. 